Original research article

\title{
Research into aggression in patients from the point of view of registered nurses in the Slovak Republic
}

\author{
Elena Janiczeková *, Jana Lauková \\ Slovak Medical University in Bratislava, Faculty of Health Care in Banská Bystrica, Banská Bystrica, Slovak Republic
}

\begin{abstract}
Introduction: Violence and aggression of patients towards nurses is encountered in nursing practice in all clinical disciplines. Aggression is conditioned by the multifactorial influence of the environment, the personality of the patient and the nurse. Compared to other health care professions, nurses are exposed to aggressive behaviour much more often.

Objective: The objective of the research was to determine whether nurses in the Slovak Republic (SR) are exposed to aggressive patient behaviour and which determinants most often condition aggressive patient behaviour.

Methods: A self-designed questionnaire with a high internal consistency Cronbach alpha coefficient (0.870) was used. The sample consisted of 439 nurses working in hospitals in nursing units. We used k proportions comparison test using Marascuilo procedure at the significance level $p<0.0001$.

Results: $99.32 \%$ of nurses have experienced aggressive patient behaviour in all nursing units (the degree of experience is significant $0.4897>0.0813$ ). Verbal aggression is statistically significantly higher than all other types of aggression (comparison test of two proportions; $\left.\mathrm{z}=13.9718 ; \mathrm{z}_{\mathrm{krit}}=2.3263 ; p=1.158 \cdot 10^{-44} \approx 0\right) .87 .70 \%$ of nurses are exposed to physical aggression $\left(p=7.316 \cdot 10^{-111} \approx 0\right)$. Conclusions: Nurses are the target of verbal and physical aggressive behaviour from patients. The most common determinants of patients' aggressive behaviour are abuse, pain, loss of self-sufficiency, the disease itself, and lack of information.
\end{abstract}

Keywords: Aggression; Aggressive behaviour; Aggressiveness; Determinants; Nurse

\section{Introduction}

Violence is one of the most common manifestations of human rights violations of individuals, groups and society as a whole. The World Health Organization (WHO) defines violence as "the intentional use of physical force or power, threatened or actual, against oneself, another person, or against a group or community, that either results in or has a high likelihood of resulting in injury, death, psychological harm, maldevelopment, or deprivation". There are two types of violence: physical, which involves the use or threat of physical force against individuals (beating, kicks, slaps, biting, stabbings, shootings, and shoves), and psychological violence, which includes verbal abuse, rude behaviour and disrespect (intimidation, bullying, harassment) (Cannavó et al., 2017). Compared to abroad, a minimal or almost no attention is paid to the occurrence and prevention of violence and aggression on nurses in the Slovak Republic (Lepiešová and Nemčeková, 2013). According to Jackson et al. (2002), the nursing profession is the most vulnerable group. Also, according to Hahn et al. (2013) and Kowalczuk and Krajewska-Kulak (2017), aggressive patient behaviour is more commonly aimed at nurses and other health care workers than doctors or oth- er specialists. Pich et al. (2017) report that nurses around the world are exposed daily to physical and verbal aggression by patients, which has become part of their profession. Wells and Bowers (2002) argue that patient violence against nurses is no exception; it has always been there, whether we are talking about actual or potential risk. Aggressive behaviour negatively affects the quality of care provided, increases stress in nurses and contributes to changing their behaviour (Pekara and Trešlová, 2011). According to Lepiešová et al. (2015), aggressive behaviour contributes to reducing the mental and physical well-being of nurses, the motivation of nurses, and worsens their work environment and satisfaction with the work performed.

Based on the above facts, we examined:

- whether nurses are the target of aggressive patient behaviour;

- what types of aggressive behaviour nurses experience most often;

- the most common determinants that can cause aggressive behaviour in a patient;

- whether the nurse's approach can influence the patient's aggressive behaviour.

\footnotetext{
* Corresponding author: Elena Janiczeková, Slovak Medical University in Bratislava, Faculty of Health Care in Banská Bystrica, Sládkovičova 21, 97405 Banská Bystrica; e-mail: elena.janiczekova@szu.sk http://doi.org/10.32725/kont.2021.011 
Table 3. Marascuilo procedure - aggressive behaviour in practice

\begin{tabular}{|c|c|c|c|c|c|}
\hline Options & $n$ & $\%$ & Marascuilo procedure $(\alpha=0.01)$ & Critical value & Significant \\
\hline Not at all & 4 & 0.91 & & & \\
\hline No & 29 & 6.61 & & & \\
\hline Sometimes & 158 & 35.99 & $p$ (yes) $-p$ (sometimes) & 0.0999 & yes \\
\hline Yes & 168 & 38.27 & $p$ (yes) $-p$ (no) & 0.0813 & yes \\
\hline Certainly yes & 80 & 18.22 & $p$ (sometimes) $-p$ (no) & 0.0793 & yes \\
\hline Total & 439 & 100.00 & \multicolumn{3}{|c|}{ Average score: $3.66 \pm 0.88$} \\
\hline
\end{tabular}

Table 4. Triggers of aggressive behaviour

\begin{tabular}{lrrc} 
Options & $n$ & \multicolumn{1}{c}{$\%$} & Mann-Whitney test \\
\hline Nurses & 20 & 4.56 & \\
Co-patients & 91 & 20.73 & \\
Other health care workers & 31 & 7.06 & $\mathrm{z}=-3.6663$ \\
Relatives & 135 & 30.75 & zkrit $=-2.3263$ \\
Other causes & $\mathbf{1 6 2}$ & $\mathbf{3 6 . 9 0}$ & \\
\hline Total & $\mathbf{4 3 9}$ & $\mathbf{1 0 0 . 0 0}$ & $\boldsymbol{p}=\mathbf{0 . 0 0 0 1 2}$ \\
\hline
\end{tabular}

Testing statistics: (z) Mann-Whitney test, level of significance $(\alpha=0.01)$. disorientation of patients, stress, changes in the environment, the patient's personality.

The Marascuilo procedure again points to the statistical significance of the difference in the relative frequencies of respondents' responses in pairs.

The percentage of respondents reporting that nurses can influence aggressive patient behaviour with their approach is statistically significantly lower than the percentage of respondents who had not experienced the situation $(0.3531>0.0907)$. The percentage of respondents who chose the option "sometimes" - nurse's approach provoked aggressive behaviour - is also lower $(0.1503>0.0871)$. The percentage of respondents who had not experienced the situation at all is also statistically significantly lower $(0.2027>0.0991)$ (Table 5).

Table 5. Marascuilo procedure - aggressive patient behaviour influenced by nurses

\begin{tabular}{|c|c|c|c|c|c|c|}
\hline Options & $n$ & $\%$ & Marascuilo procedure $(\alpha=0.01)$ & Value & Critical value & Significant \\
\hline Not at all & 35 & 7.97 & & & & \\
\hline No & 186 & 42.37 & $p$ (yes) $-p$ (sometimes) & 0.1503 & 0.0871 & yes \\
\hline Sometimes & 142 & 32.35 & $p$ (yes) $-p$ (no) & 0.3531 & 0.0907 & yes \\
\hline Yes & 65 & 14.81 & $p$ (sometimes) $-p$ (no) & 0.2027 & 0.0991 & yes \\
\hline Certainly yes & 11 & 2.50 & & & & \\
\hline Total & 439 & 100.00 & & & & \\
\hline
\end{tabular}

We also examined what type of verbal aggression respondents encountered most often during their practice.

Invectives, as a verbal type of aggression, occur in the respondents' responses to a statistically significantly higher rate than all other types combined (comparison test of two proportions; $z=13.9718 ; z_{\text {krit }}=2.3263 ; p=1.158 \cdot 10^{-44} \approx 0$ ) (Table 6).

\section{Table 6. Type of verbal aggression}

\begin{tabular}{lrrc} 
Options & \multicolumn{1}{c}{$n$} & \multicolumn{1}{c}{$\%$} & Mann-Whitney test \\
\hline Invectives & $\mathbf{3 2 3}$ & $\mathbf{7 3 . 5 8}$ & \\
Threats & 59 & 13.44 & \\
$\begin{array}{l}\text { Humiliation } \\
\begin{array}{l}\text { Other form of verbal } \\
\text { aggression }\end{array}\end{array}$ & 24 & 5.47 & $z_{\text {krit }}=2.3263$ \\
\hline Total & 33 & 7.52 & \\
\hline
\end{tabular}

Testing statistics: (z) Mann-Whitney test, level of significance $(\alpha=0.01)$.
We also examined what type of physical aggression the nurses encountered most often during their practice.

385 respondents $(87.70 \%)$ encountered the physical type of aggression - and some of them had experience with all of the types of aggression that we mentioned. Only three respondents reported other types of physical aggression (door slamming and damaging furniture by a patient).

In this case, too, the percentage of respondents who had been confronted with physical aggression significantly exceeds the percentage of respondents who had not experienced the physical type of aggression from patients (comparison test of two proportions; $\mathrm{z}=22.3414 ; \mathrm{z}_{\mathrm{krit}}=2.3263 ; p=7.316 .10^{-111}$ $\approx 0$ ).

Hand strikes, as the most common type of physical aggression of patients, occurred in the respondents' responses to a statistically significantly higher degree than all of the other types combined (comparison test of two proportions; $\mathrm{z}=9.8301 ; \mathrm{z}_{\text {krit }}=2.3263 ; p=4.176 .10^{-23} \approx 0$ ) (Table 7).

The most common determinants of patients' aggressive behaviour (as reported by the respondents) are abuse, pain, loss of self-sufficiency, the disease itself, and lack of information. 
Table 7. Type of physical aggression

\begin{tabular}{|c|c|c|c|}
\hline Options & $n$ & $\%$ & Mann-Whitney test \\
\hline \multirow[t]{2}{*}{ Hand strike } & \multirow[t]{2}{*}{275} & \multirow[t]{2}{*}{62.64} & $\begin{array}{c}z=9.8301 \\
z_{\text {krit }}=2.3263\end{array}$ \\
\hline & & & $p=4.176 .10^{-23} \approx 0$ \\
\hline Attack with an object & 66 & 15.03 & \multirow{3}{*}{$\begin{array}{c}z=22.3414 \\
z_{\text {krit }}=2.3263\end{array}$} \\
\hline Use of bodily excretions & 70 & 15.95 & \\
\hline $\begin{array}{l}\text { Other types of physical } \\
\text { aggression }\end{array}$ & 3 & 7.52 & \\
\hline Total & 439 & 100.00 & $p=7.316 .10^{-111} \approx 0$ \\
\hline
\end{tabular}

\section{Discussion}

By analyzing the obtained results and their evaluation, we found that Slovak nurses are the target of aggressive behaviour of patients to a statistically significant degree (0.4897 > 0.0813). Nurses are most often in contact with patients, so they become the first so-called "valve" between doctors and patients. Viottini et al. (2020), in a retrospective observational study involving 10,970 healthcare professionals, compared individual healthcare professions at risk of aggressive patient behaviour. They found that nurses were the group most often confronted with the aggressive behaviour of patients (64.30\%). In a quantitative cross-sectional study, Lepiesova et al. (2015) examined the experiences of nurses with aggression in selected hospitals in Slovakia. Out of a group of 1,042 nurses, up to $97.40 \%$ had faced aggressive patient behaviour in the last 12 months. The occurrence of aggressive behaviour of patients can be positively influenced by the new legal protection of healthcare professionals in the Slovak Republic, according to which the nurse has the status of a protected person (Act No. 316/2016). Furthermore, in a cross-sectional study by Kerr et al. (2017) - which examined the prevalence of aggression towards health care workers, up to $97 \%$ of respondents had experienced aggression from patients during their health careers. In their research conducted at psychiatric workplaces, Dimunová and Žemličková (2020) found personal experience with patient aggression in $97.20 \%$ of nurses. Although our research was conducted outside of psychiatric workplaces, we can report that the occurrence of aggression in other workplaces is comparable to the occurrence in psychiatric workplaces. In their research, Antonius et al. (2010) report that patients with mental illness are more aggressive. Up to $96 \%$ of respondents agree with this statement. The nurses in psychiatric wards expect aggressive patient behaviour. They are better trained in various forms of aggression compared to nurses in other workplaces - who do not receive the necessary attention in connection with aggressive patient behaviour and the problem is often marginalised.

We also identified the types of aggressive behaviour of patients that nurses encounter most often in their workplaces. We found that the nurses involved in the research have experience with both verbal and physical aggression. Verbal aggression occurs to a statistically significantly higher degree than all other types combined (comparison test of two proportions; $z=13.9718 ; z_{\text {krit }}=2.3263 ; p=1.158 .10^{-44} \approx 0$ ) (Table 6). Verbal aggression has been shown to be the most common form of aggression of patients towards nurses in several studies of a similar nature. According to Dimunová and Žemličková (2020), up to $96.80 \%$ of nurses have experienced a verbal attack from patients.

In our research, up to 385 respondents had been confronted with the physical form of aggression $-87.70 \%$ (the most frequent answer was hand strike 62.64\%). In a research sample of 447 nurses, Ahmed (2012) found that up to $39 \%$ of nurses had encountered hand strikes. Bordignon and Monteiro (2016) report up to $49 \%$ and urge nurses to be potentially prepared for an unexpected attack from patients. It is important to note that nurses who are committed to helping patients under all circumstances and conditions should make sure that patients do not physically assault them. Dimunová and Žemličková (2020) report physical aggression without the use of an offensive weapon in $83.10 \%$ cases. The use of an offensive weapon was reported by $22.80 \%$ of nurses.

In a study by Schablon et al. (2018), acts of physical aggression account for 58\%. The most common are gripping, scratching and punching. Verbal attacks were stated by $61 \%$ of nurses - these attacks mainly involved insults and threats from patients. Also, in the research of Swan et al. (2014), verbal anger was experienced by up to $93 \%$ of health workers, and physical aggression by up to $65 \%$. When analyzing the representation of individual roles, it was the nurses who experienced the largest number of aggressive incidents, compared to doctors. In a study by Lepiešová et al. (2015), nurses were most often confronted with verbal aggression from patients in the form of insults and reprimands. Jalil et al. (2017), in a study identifying the relationship between nurses' mental health and aggressive patient behaviour, found more aggressive manifestations of a verbal nature that were personally derogatory, targeted, and degrading. Kerr et al. (2017), in a cross-sectional study, report physical injury in $40 \%$ of nurses and mental injury in $82 \%$ of nurses. Verbal aggression correlated with physical aggression $(r=0.429 ; p<0.01)$. Also, Viottini et al. (2020) report the highest risk of verbal aggression in a retrospective study (3.83). Šupínová et al. (2015) also point out cultural differences that may lead to a different model of behaviour.

We found that, among the most common determinants that cause aggressive behaviour in patients, $36.90 \%$ of respondents chose the "other" option. They reported: the patient's disease itself, addiction, fear and the hospital environment. Levenson (2009) agrees with these claims, stating that alcohol and addiction are most often associated with aggression. In our research, up to $96.12 \%$ of respondents mentioned intoxicants as the cause of aggressive patient behaviour. This has also been pointed out by Beck and Heinz (2013), who state that $49.90 \%$ of aggressive patients were dependent on alcohol and other substances. We can say that regular users of intoxicants are more aggressive, as evidenced by the results of other foreign studies as well as our own.

McClelland et al. (2001) include the hospital environment among the risk factors that may elicit aggressive behaviour. In the research we conducted, $30.75 \%$ of respondents think that relatives also have a negative impact on the patient. According to Boudreaux (2010), relatives can upset, confuse and manipulate patients - and then patients become aggressive. In the study 'Experiences of healthcare workers with patients and visitors', Hahn et al. (2013) state that patient and visitor violence is the most dangerous occupational risk that healthcare staff have to deal with. Heckemann et al. (2017) consider the aggression of patients and visitors in general hospitals as a global problem that causes human suffering and organizational costs. 
In relation to whether the nurse's approach can influence the patient's aggressive behaviour, $49.66 \%$ of nurses agreed that their approach to patients could also trigger aggressive behaviour. Supínová (2013) mentions the nurse's approach as the cause of aggressive patient behaviour in only $2.90 \%$ of nurses. Hollingworth (2005) argues that a nurse's poor approach to patients is one of the main triggers of aggression. The lack of time devoted to patients is also closely related to this problem. As many as $61.96 \%$ of respondents think that a lack of time devoted to the patient can lead to the patient's aggressive behaviour towards the nurse. What is striking, however, is that even though the nurses are aware of this negative fact, they are unable to influence it on their own - due to insufficient staffing and increasing responsibilities. Needless to say, there have been a lack of nurses in the Slovak Republic for a long time; nurses are overwhelmed and thus cannot pay enough attention to patients. The Slovak Chamber of Nurses and Midwives (SKS and PA) have pointed out the fact that thousands of nurses are missing in Slovakia. According to the data of the Ministry of Health of the Slovak Republic (SKSaPA, 2019), approximately 3,500 nurses are currently missing in Slovakia. Patients often react aggressively to this fact, even though they realize that the situation needs to be addressed more comprehensively. Therefore, nurses are often unnecessarily the target of anger and aggressive behaviour. In terms of whether the nurse's mood can influence the patients aggressive behaviour, $71.30 \%$ of respondents rejected this statement (they had not experienced it during their practice). Hollingworth (2005) points out that nurses should control their emotions and not pass on their private problems to patients. Jalil et al. (2017) argue that emotions of nurses who were subjected to mild to severe physical aggression during their work were not adversely affected. It is important to realize that if such a situation occurs in practice, it is appropriate for the nurse to solve her/his problems and only then solve the patient's problems.

$61.96 \%$ of respondents believe that the most frequent cause of aggressive behaviour is the patient's illness itself. The disease itself, as a cause of aggressive patient behaviour, has been reported in several studies of a similar nature (Considine et al., 2019; Edward et al., 2014; Šupínová, 2013). Fear and pain are closely related to the problem of the disease itself; $74.48 \%$ of respondents think that fear can cause aggressive behaviour in patients. $82.23 \%$ of respondents state that pain affects the patient's behaviour to a great extent. Harwood (2017) emphasizes that fear is a factor that can significantly stimulate the patient's aggression. Margari et al. (2014) claim that patients with pain are on average up to $50 \%$ more aggressive than patients without pain.

Other determinants of patients' aggressive behaviour include reluctance to adhere to a treatment regimen. This was stated by $54.90 \%$ of respondents, with $38.04 \%$ reporting a refusal of treatment. Šupínová (2013) found that, for $44.90 \%$ of respondents, the reluctance of patients to adapt to the treatment regimen is the most common trigger of violence. Compared to our research, only $25 \%$ of respondents report the patient's disease, and $10.30 \%$ the patient's refusal of treatment, as the trigger of aggression.

Loss of self-sufficiency can also cause aggressive behaviour in a patient. This is stated by as many as $77.23 \%$ of respond- ents. However, only $5.01 \%$ of respondents are clearly convinced of this. Gallagher and Seedhouse (2002) point out that loss of self-sufficiency is closely related to loss of dignity. According to Rapčíková (2020), not only illness and its consequences, but also hospitalization, including many diagnostic and therapeutic procedures, are serious assaults on human dignity. Perceptions of dignity are also affected by the damage done to a person by significant stigmatization, radical surgery, or dying. All of these determinants may be associated with manifestations of aggressive behaviour. Furthermore, we found that up to $67.89 \%$ of respondents think that even a poorly informed patient can be aggressive. Act No. 576/2004 Coll. on Health Care, Services Related to the Provision of Health Care as amended, lays down the patient's right to information. In the performance of his/her profession, the nurse is obliged to respect the basic rights of the patient - the right to sufficient and comprehensible information. It also emerged from our research, that patient knowledge - as one of the factors determining aggressive behaviour - can be positively influenced by the nurse's approach. In the last question, we left room to list some situations that caused aggressive behaviour in patients. The respondents reported impatience, waiting for an examination or surgery, and waking up patients from anaesthesia (some patients behave aggressively). They also reported unfulfilled requirements and expectations of patients, pointless determination of conditions and lecturing of medical staff. We want nurses and patients to always find a compromise in their requirements, so that together they achieve the same goal for both parties: the highest possible level of health without any manifestations of aggression and aggressive behaviour.

\section{Conclusions}

Aggression and aggressive patient behaviour are present in nursing practice. We statistically confirmed that even nurses, who do not work in psychiatric workplaces are exposed to aggressive patient behaviour. It was also confirmed that nurses are most exposed to verbal aggression from patients. The most frequent determinants of aggressive behaviour include abuse, pain, loss of self-sufficiency, the disease itself and, last but not least, insufficient patient knowledge. Nurses are not always able to prevent aggressive behaviour and are also not able to predict with certainty what can cause aggressive behaviour in a patient. The present research shows that violence and aggression are a problem in the nursing profession. The role of nurse managers is therefore to design effective preventive measures and the maximum adherence in practice. As a precautionary measure, we propose free legal, psychologicalethical education for nurses through e-learning courses and practical workshops - thus providing them with orientation in the aggravated situations that an aggressive and non-cooperative patient creates. We also propose that nurses are required to consistently record every incident with the patient in the documentation, and that problems should be solved not only with the management of the clinic or department, but also with the management of the hospital.

\section{Conflict of interests}

The authors have no conflict of interests to declare. 


\section{Výskum agresivity u pacientov z pohl'adu registrovaných sestier v Slovenskej republike}

\section{Súhrn}

Úvod: S násilím a agresiou pacientov voči sestrám sa v ošetrovatel'skej praxi stretávame vo všetkých klinických odboroch. Agresia je podmienená multifaktoriálne vplyvom prostredia, osobnostou pacienta a sestry. Sestry sú v porovnaní s inými zdravotníckymi profesiami agresívnemu správaniu vystavené ovel'a častejšie.

Ciel': Ciel'om výskumu bolo zistit', či sú sestry v Slovenskej republike vystavené agresívnemu správaniu pacientov a ktoré determinanty najčastejšie podmieňujú agresívne správanie pacientov.

Metódy: Bol použitý dotazník vlastnej konštrukcie s vysokou internou konzistenciou Cronbach alfa koeficient - 0,870. Súbor tvorilo 439 sestier pracujúcich v nemocniciach na ošetrovacích jednotkách. Použili sme test zhody k podielov s Marascuilo procedúrou na hladine významnosti $p<0,0001$.

Výsledky: Zistili sme, že 99,32 \% sestier má skúsenosti s agresívnym správaním pacientov na všetkých ošetrovacích jednotkách (miera skúseností je významná $0,4897>0,0813$ ). Slovný typ agresie je v štatisticky významne vyššej miere ako všetky ostatné typy spolu (test zhody dvoch podielov; $\mathrm{z}=13,9718 ; \mathrm{z}_{\text {krit }}=2,3263 ; p=1,158 \cdot 10^{-44} \approx 0$ ). Fyzickej agresii je vystavených $87,70 \%$ sestier $\left(p=7,316 \cdot 10^{-111} \approx 0\right)$.

Záver: Sestry sú terčom verbálneho a fyzického agresívneho správania pacientov. Najčastejšími determinantmi agresívneho správania pacientov sú abúzy, bolest', strata sebestačnosti, samotné ochorenie a nedostatočná informovanost́.

Kl'účové slová: agresia; agresivita; agresívne správanie; determinanty; sestra

\section{References}

1. Act No. 576/2004 Coll., o zdravotnej starostlivosti, službách súvisiacich s poskytovaním zdravotnej starostlivosti a o zmene a doplnení niektorých zákonov. In: Zbierka zákonov Slovenskej republiky, čiastka 243/2004.

2. Act No. 316/2016 Coll., o uznávaní a výkone majetkového rozhodnutia vydaného v trestnom konaní v Európskej únii. In: Zbierka zákonov Slovenskej republiky.

3. Ahmed AS (2012). Verbal and physical abuse against Jordanian nurses in the work environment. East Mediterr Health J 18(4): 318-324. DOI: 10.26719/2012.18.4.318.

4. Antonius D, Fuchs L, Herbert F, Kwon J, Fried JL, Burton PRS, et al. (2010). Psychiatric Assessment of Aggressive Patients: A Violent Attack on a Resident. Am J Psychiatry 167(3): 253-259. DOI: 10.1176/appi.ajp.2009.09010063.

5. Beck A, Heinz A (2013). Alcohol-Related Aggression-Social and Neurobiological Factors. Dtsch Arztebl Int 110(42): 711-715. DOI: 10.3238/arztebl.2013.0711.

6. Bordignon M, Monteiro MI (2016). Violence in the workplace in Nursing: consequences overview. Rev Bras Enferm 69(5). DOI: 10.1590/0034-7167-2015-0133.

7. Boudreaux A (2010). Keeping your cool with difficult family members. Nursing 40(12): 48-51. DOI: 10.1097/01. NURSE.0000390673.65148.bc.

8. Cannavò M, Fusaro N, Colaiuda F, Rescigno G, Fioravanti M (2017). Violence on health care workers. Clin Ter 168(2): e99e112. DOI: 10.7417/CT.2017.1990.

9. Considine J, Berry D, Johnson R, Sands N (2019). Vital signs as predictors for aggression in hospital patients (VAPA). J Clin Nurs 26(17-18): 2593-2604. DOI: 10.1111/jocn.13646.

10. Dimunová L, Žemličková A (2020). Agresia pacientov voči sestrám vo vztahu k vybraným socio-demografickým faktorom. Zdravotnícke listy 8(1): 54-59. DOI: 2020/2020-8.c.1/ZL.

11. Edward K-L, Ousey K, Warelow P, Lui S (2014). Nursing and Aggression in the Workplace: A Systematic Review. Br J Nurs 23(12): 653-654, 656-659. DOI: 10.12968/ bjon.2014.23.12.653.

12. Gallagher A, Seedhouse D (2002). Dignity in care: The views of patients and relatives. Nurs Times 98(43): 38-40.

13. Hahn S, Müller M, Hantikainen V, Kok G, Dassen T, Halfens RJG (2013). Risk factors associated with patient and visitor violence in general hospitals: results of a multiple regression analysis. Int J Nurs Stud 50(3): 374-385. DOI: 10.1016/j.ijnurstu.2012.09.018.
14. Harwood R (2017). How to deal with violent and aggressive patients in acute medical settings. J R Coll Physicians Edinb 47(2): 94-101. DOI: 10.4997/JRCPE.2017.218.

15. Heckemann B, Peter KA, Halfens R, Schols J, Kok G, Han S (2017). Nurse managers: Determinants and behaviours in relation to patient and visitor aggression in general hospitals. A qualitative study. J Adv Nurs 73(12): 3050-3060. DOI: $10.1111 /$ jan.13366.

16. Hollingworth A (2005). The relationship between online visual representation of a scene and long-term scene memory. J Exp Psychol Learn Mem Cogn 31(3): 396-411. DOI: 10.1037/02787393.31.3.396.

17. Jackson D, Clare J, Mannix J (2002). Who would want to be a nurse? Violence in the workplace - a factor in recruitment and retention. J Nurs Manag 10(1): 13-20. DOI: 10.1046/j.09660429.2001.00262.x.

18. Jalil R, Huber JW, Sixsmith J, Dickens GL (2017). Mental health nurses' emotions, exposure to patient aggression, attitudes to and use of coercive measures: Cross sectional questionnaire survey. Int J Nurs Stud 75: 130-138. DOI: 10.1016/j. ijnurstu.2017.07.018.

19. Kerr K, Oram J, Tinson H, Shum D (2017). Health Care Workers' Experiences of Aggression. Arch Psychiatr Nurs 31(5): 457-462. DOI: 10.1016/j.apnu.2017.06.011.

20. Kowalczuk K, Krajewska-Kułak E (2017). Patient aggression towards different professional groups of healthcare workers. Ann Agric Environ Med 24(1): 113-116. DOI: $10.5604 / 12321966.1228395$.

21. Lepiešová $M$, Nemčeková $M$ (2013). Násilie a agresia voči sestrám pri výkone povolania. Sociológia 45(2): 172-194.

22. Lepiešová M, Tomagová M, Bóriková I, Farský I, Žiaková K, Kurucová R (2015). Experience of nurses with in-patient aggressoin in the Slovak Republic. Cent Eur J Nurs Midw 6(3): 306-312. DOI: 10.15452/CEJNM.2015.06.0020.

23. Levenson JL (2009). Text Book of Psychosomatic Medicine and Consultation-Liaison Psychiatry. 3rd ed. Am Psychiatr Assoc Pub, $1594 \mathrm{p}$.

24. Margari F, Lorusso M, Matera E, Pastore A, Zagaria G, Bruno F, et al. (2014). Aggression, impulsivity, and suicide risk in benign chronic pain patients - a cross-sectional study. Neuropsychiatr Dis Treat 10: 16113-1620. DOI: 10.2147/NDT.S66209.

25. McClelland N, Humphreys M, Conlon L, Hillis T (2001). Forensic Nursing and Mental Disorder in Clinical Practice. Oxford: Butterworth-Heinemann, $160 \mathrm{p}$.

26. Pekara J, Trešlová M (2011). Prevence násilí v ošetřovatelství. Prevence úrazů, otrav a násilí 7(2): 187-191. 
27. Pich V J, Kable A, Hazelton M (2017). Antecedents and precipitants of patient-related violence in the emergency department: Results from the Australian VENT Study (Violence in Emergency Nursing and Triage). Australas Emerg Nurs J 2(3): 107-113. DOI: 10.1016/j.aenj.2017.05.005.

28. Rapčíková T (2020). Vybrané kapitoly zo zdravotníckej etiky 1. Banská Bystrica: Dali-BB, $116 \mathrm{p}$

29. Schablon A, Wendeler D, Kozak A, Nienhaus A, Steinke S (2018). Prevalence and Consequences of Aggression and Violence towards Nursing and Care Staff in Germany-A Survey. Int J Environ Res Public Health 15(6): 1274. DOI: 10.3390/ ijerph15061274.

30. Slovak Chamber of Nurses and Midwives [Slovenská komora sestier a pôrodných asistentiek - SKSaPA] (2019). Ošetrovatel'stvo a pôrodná asistencia (3): 11.

31. Šupínová M (2013). Agresivita ako faktor determinujúci komunikáciu v ošetrovatel'skej praxi. In: Nové trendy vo vzdelávaní a praxi ošetrovatel'stva a pôrodnej asistencie (vyd.) Ružomberok: Verbum, pp. 44-51.
32. Šupínová M, Hegyi L, Klement C (2015). Zdravotný stav Rómov na Slovensku. Hygiena. 60(3): 116-119. DOI: 10.21101/ hygiena.a1334.

33. Swain N, Gale C, Greenwood R (2014). Patient aggression experienced by staff in a public hospital setting. NZ Med J 127(1394): 10-18.

34. Viottini E, Politano G, Fornero G, Pavanelli PL, Boreli P, Bonaudo M, Gianino MM (2020). Determinants of aggression against all health care workers in a large-sized university hospital. BMC Health Serv Res 20(215): 107-113. DOI: 10.1186/s12913-020-05084-x.

35. Wells J, Bowers L (2002). How prevalent is violence towards nurses working in general hospitals in the UK? J Adv Nurs 39(3): 230-240. DOI: 10.1046/j.1365-2648.2002.02269.x.

36. WHO (2002). World report on violence and health. Geneva: WHO, $360 \mathrm{p}$. 